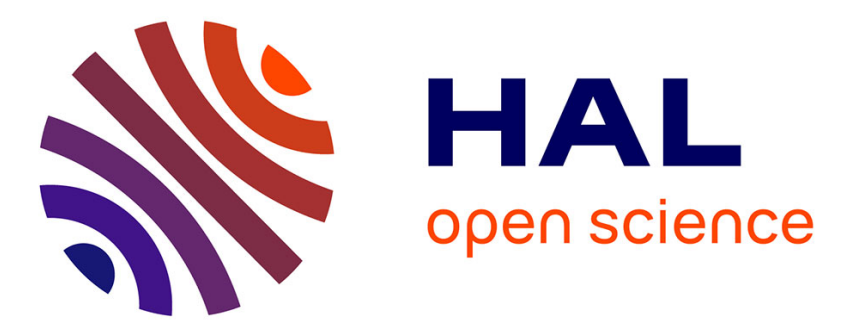

\title{
MODELING OF LPCVD SILICON NITRIDE PROCESS
}

\author{
Ji-Tao Wang, Shi-Li Zhang, Yong-Fa Wang, Wei Zhang, Zheng-Chang Chen, \\ Ke-Yun Zhang, Yuan-Fang Wang
}

\section{- To cite this version:}

Ji-Tao Wang, Shi-Li Zhang, Yong-Fa Wang, Wei Zhang, Zheng-Chang Chen, et al.. MODELING OF LPCVD SILICON NITRIDE PROCESS. Journal de Physique Colloques, 1989, 50 (C5), pp.C5-67C5-72. 10.1051/jphyscol:1989511 . jpa-00229534

\section{HAL Id: jpa-00229534 https://hal.science/jpa-00229534}

Submitted on 1 Jan 1989

HAL is a multi-disciplinary open access archive for the deposit and dissemination of scientific research documents, whether they are published or not. The documents may come from teaching and research institutions in France or abroad, or from public or private research centers.
L'archive ouverte pluridisciplinaire HAL, est destinée au dépôt et à la diffusion de documents scientifiques de niveau recherche, publiés ou non, émanant des établissements d'enseignement et de recherche français ou étrangers, des laboratoires publics ou privés. 
MODELING OF LPCVD SILICON NITRIDE PROCESS

JI-TAO WANG ${ }^{(1)}$, SHI-LI ZHANG (2), YONG-FA WANG, WEI ZHANG, ZHENG-CHANG CHEN, KE-YUN ZHANG and YUAN-FANG WANG

Fudan University, 220 Handan Road, Shangai, China

Résumé - Une grande attention a été accordée par divers groupes de recherche et divers auteurs à la modélisation du procédé CVD sous basse pression. Notre modèle a été proposé en 1979 et 1980 , puis amélioré et étendu plusieurs fois. La simulation repose sur des formules algébriques faciles à utiliser. Dans nos publications précédentes, ce modèle a été utilisé avec succés pour le dépôt de silicium polycristallin. Dans le présent article, il est utilisé dans le cas du dépôt de $\mathrm{Si}_{3} \mathrm{~N}_{4}$. Les résultats théoriques sont en bon accord avec les résultats expérimentaux cités dans la littérature.

\begin{abstract}
Much attention has been paid to the modeling of LPCVD process by several research groups and authors. Our simulation model of LPCVD process was proposed in 1979 and 1980, and then improved and extended several times. Our simulation formulae are algebraic, so it is easy to be used. Our model was successfully used for the LPCVD Poly-Si process in our previous papers, and also for the LPCVD $\mathrm{Si}_{3} \mathrm{~N}_{4}$ process in this paper. The theoretical results agree very well with experiments reported in literature.
\end{abstract}

\title{
$1 \quad$ INTRODUCTION
}

Chemical Vapor Deposition is a widely used process for growing thin films in large scale integrated circuit technology. At low pressure the deposition process becomes essential surface controlled which allows high packing densities of the wafer, see Fig. 1. Much attention has been paid to the modeling of LPCVD process by several research groups and authors. Our simulation model of LPCVD process was proposed in 1979-1980 [1,2], and then improved and extended several times during 1981-1988 [3-11]. As well known, it is most important for any theoretical model that the theoretical results must agree with the experimental ones. In 1986, a comparison with a good agreement was made by us [7] between our theoretical model and LPCVD Poly-Si experiments, reported mainly by van den Brekel,

\footnotetext{
(1) Uppsala University, Institute of Chemistry, Box 531, S-751 21 Uppsala, Sweden

(2) Swedish Institute of Microelectronics, S-16421 Kista, Sweden
} 
Claassen and Kuiper et al. [12-14]. In this paper we make a comparison between our model and LPCVD $\mathrm{Si}_{3} \mathrm{~N}_{4}$ experiments reported by Roenigk \& Jensen $[15,16]$.

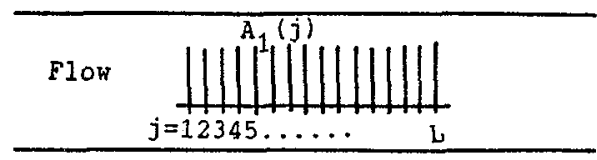

Fig 1. Theoretical model for LPCVD technology.

The kinetics of the reaction in $\mathrm{Si}_{3} \mathrm{~N}_{4}$ process is more complex than that in Poly-Si process. If only the interaction between chlorosilane and $\mathrm{NH}_{3}$ is under consideration, the calculated results will not agree with the experiments. It can be observed that the experimental deposition rate near the inlet end decreased very quickly along the flow direction and this phenomenon was more obvious at higher temperature. Besides the interaction between chlorosilane and $\mathrm{NH}_{3}$, the pyrolysis of $\mathrm{NH}_{3}$ is also one of main causes for this kind of the rate distribution. Based on the kinetics mentioned above, the agreement of our model with many LPCVD $\mathrm{Si}_{3} \mathrm{~N}_{4}$ experiments were obtained. And some inaccuracy of LPCVD $\mathrm{Si}_{3} \mathrm{~N}_{4}$ experimental data in literature were found.

\section{DERIVATION OF THEORETICAL EXPRESSION}

The main reactions in $\mathrm{LPCVD} \mathrm{Si}_{3} \mathrm{~N}_{4}$ process are:

1. Interaction between chlorosilane and $\mathrm{NH}_{3}$ $\mathrm{SiH}_{2} \mathrm{Cl}_{2}+4 / 3 \mathrm{NH}_{3}===1 / 3 \mathrm{Si}_{3} \mathrm{~N}_{4}+2 \mathrm{HCl}+2 \mathrm{H}_{2}$

2. Pyrolysis of $\mathrm{NH}_{3}$

$$
\mathrm{NH}_{3}===1 / 2 \mathrm{~N}_{2}+3 / 2 \mathrm{H}_{2}
$$

The kinetic expressions of these reactions are:

$r_{1}=\frac{K_{s} \cdot P_{\mathrm{SHH}_{2} \mathrm{Cl}_{2}} \cdot P_{\mathrm{NH}_{3}}}{1+K_{1} \cdot P_{\mathrm{SHH}_{2} \mathrm{Cl}_{2}}+K_{2} \cdot P_{\mathrm{NH}_{3}}}$

and

$\mathbf{r}_{\mathbf{z}}=\mathrm{K}_{\mathrm{d}} \cdot \mathrm{P}_{\mathrm{NH3}} \cdot$

According to the principles mentioned in our previous papers, the simulation formulae of LPCVD $\mathrm{Si}_{3} \mathrm{~N}_{4}$ can be derived. If no inert gas was used during LPCVD $\mathrm{Si}_{3} \mathrm{~N}_{4}$ reaction, that is, only two reactants, $\mathrm{SiH}_{2} \mathrm{Cl}_{2}$ and $\mathrm{NH}_{3}$, were used and the ratio of $\mathrm{NH}_{3}$ to $\mathrm{SiH}_{2} \mathrm{Cl}_{2}$ was equal to $\mathrm{N}$, then initial concentrations in mole fraction were:

1. Initial concentration of $\mathrm{SiH}_{2} \mathrm{Cl}_{2}, \mathrm{X}_{1}=1 /(\mathrm{N}+1)$,

2. Initial concentration of $\mathrm{NH}_{3}$ was equal to $\mathrm{N} /(\mathrm{N}+1)$. 
The initial concentration of $\mathrm{NH}_{3}$ could be divided into two parts:

1. Stoichiometric $\mathrm{NH}_{3}$ part was equal to $4 / 3(\mathrm{~N}+1)$

2. Excess $\mathrm{NH}_{3}$ part, $\mathrm{X}_{2}=(\mathrm{N}-4 / 3) /(\mathrm{N}+1)$

When the conversion percentage of $\mathrm{SiH}_{2} \mathrm{Cl}_{2}$ and the conversion percentage of excess $\mathrm{NH}_{3}$ were represented by $A_{1}$ and $A_{2}$, respectively, then increment of total gas volume,

$\mathrm{V}=1+(5 / 3) \cdot \mathrm{X}_{1} \cdot \mathrm{A}_{1}+\mathrm{X}_{2} \cdot \mathrm{A}_{2}$

concentration of $\mathrm{SiH}_{2} \mathrm{Cl}_{2}$,

$\mathrm{C}_{1}=\mathrm{X}_{1}\left(1-\mathrm{A}_{1}\right) / \mathrm{V}$

concentration of $\mathrm{NH}_{3}$,

$C_{2}=\left[4 X_{1}\left(1-A_{1}\right) / 3+X_{2}\left(1-A_{2}\right)\right] / V ;$

and the kinetic expressions could be written as

$r_{1}=K_{8} \cdot C_{1} \cdot C_{2} \cdot P^{2} /\left(1+K_{1} \cdot C_{1} \cdot P+K_{2} \cdot C_{2} \cdot P\right)$,

and

$\mathrm{r}_{2}=\mathrm{K}_{\mathrm{d}} \cdot \mathrm{C}_{2} \cdot \mathrm{P}$.

That is, at $\mathrm{j}$ wafer position

$r_{1}(j)=K_{8} \cdot C_{1}(j) \cdot C_{2}(j) \cdot P^{2} /\left(1+K_{1} \cdot C_{1}(j) \cdot P+K_{2} \cdot C_{2}(j) \cdot P\right)$,

and

$r_{2}(j)=K_{d} \cdot C_{2}(j) \cdot P$.

Then $A_{1}, A_{2}$ at $j+l$ wafer position

$A_{1}(j+1)=\sum_{i=0}^{j} r_{1}(i) \cdot S(i) \cdot w / F \cdot X_{1}$

$A_{2}(j+1)=\sum_{i=0}^{j} r_{2}(i) \cdot S(i) / F \cdot X_{2}$

Here, $\mathbf{w}$ was the ratio of solid deposit volume to $\mathrm{SiH}_{2} \mathrm{Cl}_{2}$ gas volume consumed. The pyrolysis of $\mathrm{NH}_{3}$ is also considered as a surface process, so the consumption of $\mathrm{NH}_{3}$ pyrolysis was proportional to $r_{2}(i) . S(i)$, as shown in $A_{2}(j+1)$ equation. In this way two sets of recurrence formulae were obtained. The curves of $r_{1}(j)$ vs. the wafer position $j$ were the theoretical distributions of growth rate. 


\section{DISCUSSIONS AND RESULTS}

1. A series of comparison between our simulation model and LPCVD $\mathrm{Si}_{3} \mathrm{~N}_{4}$ experiments were made with very good agreement in tendency, as shown in Fig. 2 to 5 . The dotted lines were theoretical ones, the square points were experimental data [17].

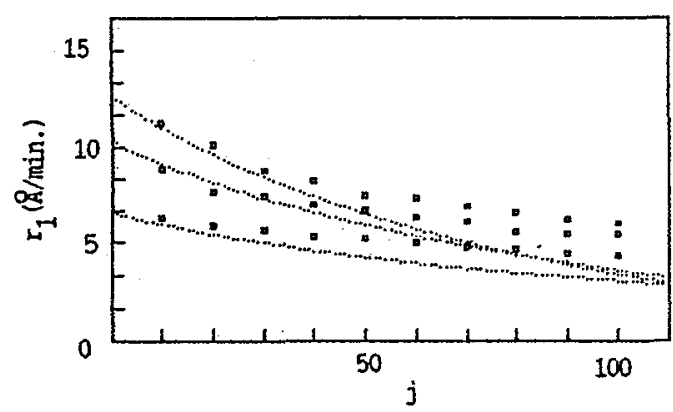

Fig. 2 Comparison between experiments a and our model..... Experimental parameters:\# $800^{\circ} \mathrm{C}, \mathrm{SiH}_{2} \mathrm{Cl}_{2} \cdot 10 \mathrm{sccm}, \mathrm{NH}_{3} / \mathrm{SiH}_{2} \mathrm{Cl}_{2}$. From up to down, first set: $\mathrm{N}=15, \mathrm{P}=0.95$ torr second set: $N=10, P=0.65$

torr

third set: $N=5, P=0.35$ torr

Apparent kinetic parameters used in calculation: $\mathrm{K}_{\mathrm{s}}=3.8 \times 10^{7} \mathrm{~A} / \mathrm{min} \cdot \mathrm{torr}^{2} \mathrm{~K}_{1}=2.0 \times 10^{5} /$ torr $\mathrm{K}_{2}=1.8 \times 10^{4} /$ torr $\mathrm{Kd}=.005 \mathrm{sccm} /$ torr. $\mathrm{cm}^{2}$

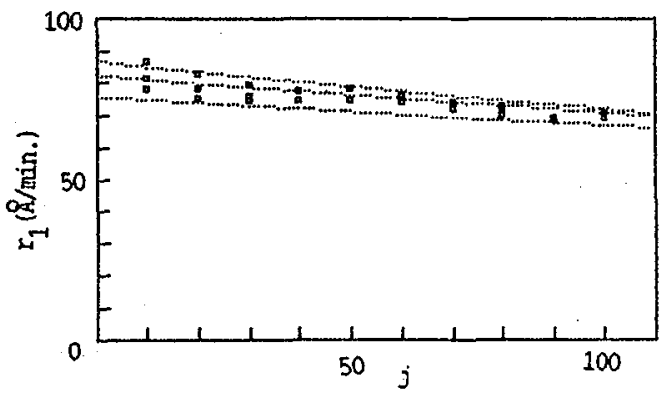

Fig 4. Comparison between experimentsa and our model... Experimental parameters:\# $700^{\circ} \mathrm{C}, \mathrm{P}=0.55$ torr, $\mathrm{SiH}_{2} \mathrm{Cl}_{2} 25 \mathrm{sccm}, \mathrm{N}=$ $\mathrm{NH}_{3} / \mathrm{SiH}_{2} \mathrm{Cl}_{2}$

From up to down, first set: $\mathrm{N}=2$ second set: $\mathrm{N}=3$ third set: $N=4$

Apparent kinetic parameters used in calculation: $\mathrm{K}_{\mathrm{r}}=2.54 \times 10^{5} \mathrm{~A} / \mathrm{min}$ torr $^{2} \mathrm{~K}_{1}=4.0 \times 10^{3} /$ torr $\mathrm{K}_{2}=1.2 \times 10^{3} /$ torr $\mathrm{Kd}=.0006 \mathrm{sccm} /$ torr. $\mathrm{cm}^{2}$

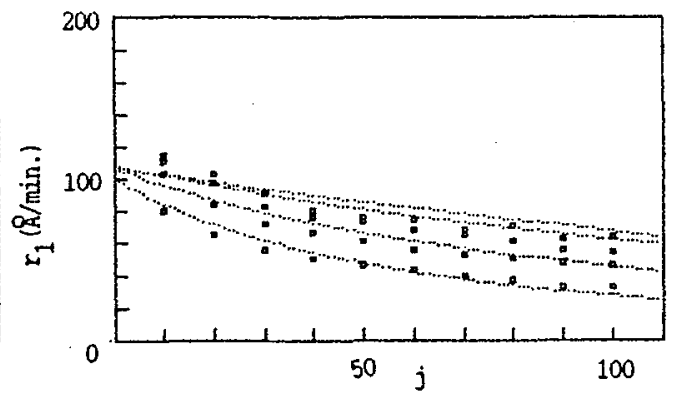

Fig. 3 Comparison between experiments $₫$ and our model.... Experimental parameters:\# $800^{\circ} \mathrm{C}, \mathrm{P}=0.95$ torr, $\mathrm{SiH}_{2} \mathrm{Cl}_{2} 25 \mathrm{sccm}$, $\mathrm{N}=\mathrm{NH}_{3} / \mathrm{SiH}_{2} \mathrm{Cl}_{2}$

From up to down, first set: $\mathrm{N}=12$, second set $N=8$ third set: $N=4$ fourth set: $N=2$

Apparent kinetic parameters used in calculation: $\mathrm{K}_{\mathrm{s}}=3.8 \times 10^{7} \mathrm{~A} / \mathrm{min} . \mathrm{torr}^{2} \mathrm{~K}_{1}=2.0 \times 10^{5} /$ torr.cm $\mathrm{cm}^{2}$ $\mathrm{K}_{2}=1.8 \times 10^{3} /$ torr $\mathrm{Kd}=.005 \mathrm{sccm} /$ torr. $\mathrm{cm}^{2}$

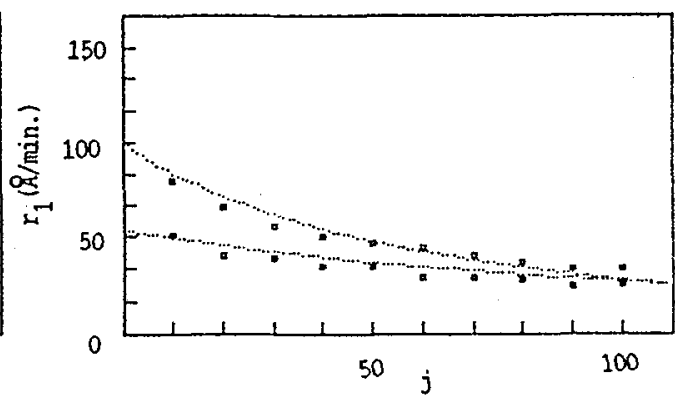

Fig 5. Comparison between experiments $\bullet$ and our model... Experimental parameters:\# $\mathrm{P}=0.95$ torr, $\mathrm{SiH}_{2} \mathrm{Cl}_{2} 25 \mathrm{sccm}, \mathrm{N}=2, \mathrm{~N}=$ $\mathrm{NH}_{3} / \mathrm{SiH}_{2} \mathrm{Cl}_{2}$

From up to down, first set: $\mathrm{T}=800^{\circ} \mathrm{C}$ second set: $\mathrm{T}=750^{\circ} \mathrm{C}$

Apparent kinetic parameters used in calculation for $750^{\circ} \mathrm{C}$ :

$\mathrm{K}_{\mathrm{z}}=3.0 \times 10^{6} \mathrm{~A} / \mathrm{min} \cdot \mathrm{torr}^{2} \mathrm{~K}_{\mathrm{i}}=3.0 \times 10^{4} /$ torr $\mathrm{K}_{2}=1.7 \times 10^{3} /$ torr $\mathrm{Kd}=.002 \mathrm{sccm} /$ torr. $\mathrm{cm}^{2}$ For $800^{\circ} \mathrm{C}$ are the same as these in Fig. 3. 
2. The values of theoretical curves at right side (downstream of the gas flow) were mostly lower than those of experimental data (especially in Fig. 2). The area under the experimental growth rate distribution curve (such as solid lines in Fig. 2) was proportional to the total consumption of reactant $\mathrm{SiH}_{2} \mathrm{Cl}_{2}, \mathrm{~A}_{1}{ }^{\text {total }}$. It was found $\mathrm{A}_{1}{ }^{\text {lotal }}$ of the solid line in Fig. 2 was near one hundred percent (94.9\%). If the consumption before the first wafer and after the last wafer was considered, the value of $\mathrm{A}_{1}^{\text {total }}$ would be more than one hundred percent. Of course, it was unreasonable. It must be due to the inaccuracy of experimental data. Maybe, it is due to the corrosion of massflow controller after some time of using chlorosilane. The inaccuracy of experimental data may also be one of the causes of that some adjustment of kinetic parameters were needed for different figures in our calculations. The adjustment of kinetic parameters [2] or even the change of reaction condition values [17] had also been reported.

3. The consumption before the wafer region was considered in our calculation here as that of the first ten wafers, but not for the Fig. 2.

4. Our simulation formulae of $\mathrm{LPCVD} \mathrm{Si}_{3} \mathrm{~N}_{4}$ are all algebraic, so they are easy to be used. And the agreement between our model and experiments was good.

\section{ACKNOWLEDGEMENT}

We thank the National Natural Science Foundation of China for grant No. 5880096 in support of this work. We also thank Prof. Jan.Otto Carlsson for giving us support, Dr Mats Boman, Nils-Olov Ersson et al. for their help, and Mrs. Margit Hillberg for making this manuscript.

\# Geometric parameters of reactor: Inside diameter of quartz tube: $130 \mathrm{~mm}$

Diameter of wafers: $\quad 76.2 \mathrm{~mm}$

110 Wafers loaded

Wafer spacing $4.8 \mathrm{~mm}$ 


\section{REFERENCES}

[1] J.-T. Wang, Anniversary Scientific Seminar of Fudan Univ., on May 27, 1979; J.-T. Wang \& Y.-K. Liu, Proc. of 1st Chinese National Conf. on Semicond. Materials and IC, in Chinese, p. 14, 1979

[2] J.-T. Wang, Chinese J. Semicond., 1, (1980) 6, with English abstract.English translation:

J.-T. Wang, Chinese Phys. (published in U.S.), 1, (1981) 461

[3] J.-T. Wang, Sciential Sinica (series A), Eng. ed., 26 (1983) 273

[4] J.-T. Wang, S.-L. Zhang, H.-J. Wang \& M.-H. Lian, Chinese J. Semicond., 5 (1984) 621, with Eng. abstract

[5] J.-T. Wang, S.-L. Zhang, H.-J. Wang \& M.-H. Lian, Proc. of 5th Euro. Conf. on CVD, p. 99, Uppsala, Sweden (June 17-20, 1985)

[6] J.-T- Wang et al., "Selected book on CVD --- part I, Computer Simulation of LPCVD", Eng. edition, Fudan Univ. Press (1985, Shanghai)

[7] J.-T. Wang, S.-L. Zhang \& Y.-F. Wang, Solid-State Electronics, 29 (1986) 999

[8] J.-T. Wang, S.-L. Zhang \& Y.-F. Wang, Proc. of Beijing International Conf. on Semicond. \& IC Technology, p. 232, Beijing, China (1986)

[9] J.-T. Wang \& S.-L. Zhang, Scientia Sinica (series A), 30 (1987) 523

[10] J.-T. Wang, S.-L. Zhang \& Y.-F. Wang, Proc. of International Conf. on CVD (Hawaii), p. 23. The Electrochem. Soc., Inc., Princeton, N.J. (1987)

[11] Y.-F. Wang, S.-L. Zhang \& J.-T. Wang, Proc. of International Conf. on CVD (Hawaii), p. 951. The Electrochem. Soc., Inc., Princeton, N.J. (1987)

[12] C.J.H. van den Brekel \& L.M. Bollen, J. Cryst. Growth, 54 (1981) 310

[13] A.E.T. Kuiper, C.J.H. vand den Brekel, J. de Groot \& G.W. Veltkamp, J. Electrochem. Soc., 129 (1982) 2288

[14] W.A.P. Claassen, J. Bloem, W.G.J.N. Valkenburg \& C.J.H van den Brekel, J. Cryst. Growth, $\underline{57}$ (1981) 259

[15] K.F. Roenighk \& K.F. Jensen, Proc. of 5th Euro. Conf. on CVD, p. 207. Uppsala, Sweden (June 17-20, 1985)

[16] K.F. Roenigk \& K.F. Jensen, J. Electrochem. Soc., 134 (1987) 1777

[17] K.F. Jensen \& D.B. Graves, J. Electrochem. Soc., 130 (1983) 1950 